\title{
The Problem with the Fragments: \\ Kierkegaard on Subjectivity and Truth
}

\section{MARILYN PIETY \\ MCGill University}

The expresston "the Iplroblem of the Fragments" actually comes not from the Fragments, ${ }^{1}$ but from the Concluding Unscientific Postscript. ${ }^{2}$ It is also this latter work that places so much overt emphasis upon subjectivity. The Fragments has, in fact, fallen out of favor with some scholars who consider it too "objective" and hence neglect it in favor of the Postscript where, they contend, the real substance of Kierkegaard's thought is to be found..$^{3}$

It is my view, however, that such claims are based upon a cursory or uncritical reading of the Fragments. I shall argue, in the pages which follow, that a careful reading will reveal that there is a discrepancy between the form of the work and its content. That is, I shall attempt to show that while Climacus, the pseudonymous author of the Fragments, claims not to be biased in favor of either of the two interpretations of the relation of the individual to the truth that he presents in that work, the "Interlude"4 section of the Fragments implicitly subverts the pretended objectivity of the work as a whole. I shall argue further that this discrepancy is intended by Klerkegaard to indirectly communicate ${ }^{5}$ to his reader that an objective

1Søren Kierkegaard, Philosophical Fragments; Johannes Climacus, trans. Howard V. Hong and Edna H. Hong (Princeton: Princeton University Press, 1985).

${ }^{2}$ Soren Klerkegaard, Concluding Unscientific Postscript, trans. David F. Swenson and Walter Lowrie (Princeton: Princeton University Press, 1941) pp. 322-46/Samlede Vaerker, ed. A. B. Drachman, J. L. Heiberg, and H. O. Lang (Kobenhavn: Gyldendal, 1963), pp. 60-82.

${ }^{3}$ The most ardent proponent of this view is Jeremy Walker. Walker makes this claim on the basis of computer analyses done on the two texts by Alastair McKinnon. McKinnon, however, holds a somewhat more moderate position. He believes that while the works are unquestionably related, the relation is not as strong as it has traditionally been considered to be.

${ }^{4}$ Fragments, pp. 72-88/Samlede Vaerker, Vol. 6.

5 The view that indirect communication is in many ways superior to direct communication is developed throughout the Postscript. The references are too numerous to be listed here. The reader will find them listed, however, under the heading "Communication" in the index to the Postscript. 
resolution of the question of the relation of the individual to the truth is impossible and that the reader must thus fall back upon the character of his subjective experience if he 18 to have the hope of finding an answerand in particular, the proper answer-to this question.

It will, of course ultimately be left to the reader to determine whether or not I have been successful in demonstrating what I have set out to demonstrate in this paper. If 1 have been successful, however, then it will become apparent that, contrary to the view held by some very prominent Kierkegaard scholars, the Fragments does not represent a departure from the emphasis which Kierkegaard places upon subjectivity in the Postscript and hence that it is as valuable a resource for determining the substance of Kierkegaard's thought as is this latter work.

1

The "Iplroblem of the Fragments", as Kierkegaard refers to It, is expressed on the title page in the following question:

Can a historical point of departure be given for an eternal consciousness; how can such a point of departure be of more than historical interest; can an eternal happiness be built on historical knowledge?

Kierkegaard does not, however, begin the Fragments by attacking this problem directly, but turns instead to consideration of the question of whether or not the truth will admit of being learned.

He first considers this question from the classical or "Socratic"6 perspective. On the Socratic account, he explains, the individual is seen as essentially in possession of the truth, but accidentally in a state of forgetfulness. On this view, a teacher-i.e., an individual who would reveal the truth to the one who was in a state of forgetfulness-is not, in the strict sense, necessary. That is, on this view, anything from a teacher to the act of tripping over a stone could serve as an occasion to jog the individual's memory concerning the truth of which he is already essentially in possession. It is clear to Kierkegaard, however, that such an account of the relation of the individual to the truth deprives the point in time at which the individual, or learner, remembers the truth of any decisive

6I have put 'Socratic' in quotation marks here because there is some question as to whether the position that Kierkegaard attributes to Socrates ought actually be attributed to him. This is not an insignificant issue. It does not, however, have any bearing upon the thesis being advanced in this paper, and so I do not intend to address it here. 
significance. On this account, the moment [Øieblikket ${ }^{7}$ at which the truth is remembered becomes instantly hidden in the eternity of the truth which is remembered

assimilated into it in such a way that [the learner], 80 to speak,...cannot find it, even if (he) were to look for $\mathrm{it}$, because lin eternityl there is no Here and no There, but only a ubique et nusquam [everywhere and nowhere]. ${ }^{8}$

On this view, the individual does not really learn the truth, but only remembers that he has always known it. Thus it cannot be said that when the individual remembers the truth, he undergoes any substantive transformation, like that exemplified in the transition from ignorance to knowledge.

Kierkegaard then speculates that perhaps an alternative understanding of the relation of the individual to the truth is possible. He even suggests that perhaps an alternative interpretation might, in some way, represent an advance upon the Socratic interpretation. It is with this alternative interpretation that Klerkegaard is primarily concerned in the Fragments. On this view, the individual is seen as essentially ignorant, or outside of the truth, and-in contrast to the Socratic view-the only thing which may serve to put the individual into the proper relation to the truth is the teacher. But this teacher is presented not merely as enlightening the learner, but as effecting a substantive transformation of him.

That is, Kierkegaard points out that if the learner is considered to be essentially ignorant or outside of the truth, then he cannot even be in possession of the condition for understanding it, "because the condition for understanding the truth is like being able to ask about it-the condition and the question contain the conditioned and the answer." ${ }^{.9}$ Thus the learner, on this view, needs to be given not only the truth, but the condition for receiving the truth, and to be made receptive to the truth in this way appears to involve a qualitative transformation of the individual.

What interests Kierkegaard about this latter interpretation is the fact that the point in time at which such a transformation of the learner is effected, is clearly of essential significance to the individual. Thus

7 This term should not be confused with Moment. While both Dieblik and Moment are translated as 'moment', the former refers to an instant, or to a point in time, while the latter is equivalent to Hegel's Moment, which is more properly translated as 'stage' or 'phase'.

8 bid., p. 13/ p. 18.

${ }^{9}$ Ibid., p. 14/ p. 19. 
Kierkegaand speculates that if this latter interpretation is correct, then an advance will have been made upon Socrates. That is, an advance will have been made insofar as the moment, or the point in time at which the learner comes into possession of the truth, will have been imbued with the eseential or decisive significance that it lacked on the Socratic account.

\section{II}

It is now necessary for me to depart for a moment from the text of the Fragments and to elucidate what I take to be Kierkegaard's objective here in a more direct manner. What Kierkegaard is trying to point out to his reader is that the Socratic interpretation of the relation of the individual to the truth deprives the temporal nature of the individual's existence of any real significance. Or, to put it even more plainly: The Socratic interpretation negates the reality of the temporal aspect of human existence, in favor of the eternal nature of the truth. On the Socratic account, temporal or phenomenal events can have nothing more than accidental significance, thus the entire temporal or phenomenal ${ }^{10}$ aspect of the individual's existence is viewed as non-essential.

Whether or not it is proper for Kierkegaard to ascribe such a view to Socrates is not at issue here."I It should be clear to the reader, however, that the desire to reject any claim to reality that may be made on behalf of the temporal or phenomenal nature of existence is one that goes back through classical philosophy as far as Parmenides. What Kierkegaand is suggesting in his Fragments is that perhaps there is a coherent interpretation of the relation of the individual to the truth, that would not commit us to rejecting the reality of time.

Climacus--the pseudonymous author of the Fragments-contends, however, that he has no essential bias toward one or the other of the two interpretations that he presents in the Fragments. He does not-or so he argues-try to persuade his reader that the alternative to the Socratic interpretation must be correct. He contends that he is merely involved in a "It]hought [p]roject"12 and that he thus has no essential interest in the outcome.

My suggestion is, however, that Kierkegaard is by no means so disinterested. It is my contention that there is a discrepancy between

10The term 'phenomenal' is particularly appropriate here as it stems from the Greek paivouEva, which refers to appearances which may, or may not, have correspondent reality.

$1^{11}$ See note 6 above.

$12_{\text {Ibid., p. } 9 / \text { p. } 15 .}$ 
Climacus' claim to objectivity and the substantive content of the Fragments. I believe, further, that this discrepancy was deliberate and that it was designed by Kierkegaard in order to point out-albeit indirectly- to his reader that a truly objective or disinterested contemplation of the issue of the nature of one's relation to the truth is either impossible or necessarily inconclusive.

\section{III}

While the Fragments is divided into several sections, there is a fundamental division between the first and the second half of the book. In the first half, the problem is set up and the situation of the non-Socratic learner is described. Kierkegaard does not, until the very end of the book, explicitly identify this alternative understanding of the relation of the individual to the truth as the Christian understanding. This is not, however, a fact which Kierkegaard believed was at any point obscure to the reader. The "teacher", on this account, is quite clearly meant to be understood by the reader to be Christ.

Immediately preceding the section of the Fragments which divides the book into its two conceptual halves, is a section entitled "The Contemporary Follower. ${ }^{13}$ This section describes the situation of the Individual who is contemporary with Christ. After this section-though not immediately after, as we shall presently see-is a section entitled "The Follower at Second Hand"14 which describes the situation of the individual who lives some time after the death of Christ, either immediately after or a number of years after, with the emphasis placed upon the situation of the individual who lives approximately eighteen hundred years later.

Between these two sections Kierkegaard inserts a brief meditation on an apparently unrelated philosophical issue. This section is entitled the "Interlude" and Kierkegaard asserts that it is there to divert briefly the attention of the reader, from consideration of the problem of the Fragments, with some light entertainment. He explains that in a play, when one desires to represent the passage of time between acts, an analogous tactic is often employed. In such instances, he continues "...the orchestra sometimes plays a symphony ${ }^{15}$ or something similar in order to

${ }_{13}$ Mid., Pp. 555-71/ Pp. $53-66$.

14 Irid., pp. 89-110/ pp. 81-98.

${ }^{15}$ The Danish term here is "e Symphoni". The rendering of this word in English as 'symphony' is rather unfortunate insofar as it is slightly misleading. 'En Symphoni' in nineteenth century Danish could mean anything from a large orchestra piece to the more modest compositions 
shorten the time by filling it up."16 Thus he explains that he has decided to fill in the eighteen hundred years that intervene between the follower who is contemporary with Christ and the nineteenth century follower, by pondering, briefly, the question of whether the past can be considered to be more necessary than the future, or whether the possible, by becoming actual, becomes more necessary than it was.

Now I have arrived at the point where my thesis finally begins to take shape. My contention is that the question with which the "Interlude" is concerned is by no means unrelated to the problem of the Fragments. If this does not seem a particularly novel suggestion, I shall go even further and argue that not only is the question of the "Interlude" significantly related to the problem of the Fragments, but that it deliberately subverts the pretended objectivity of the work. To accept what is said in the "Interlude", I shall argue, is to express a definite preference for the alternative to the Socratic understanding of the relation of the individual to the truth. If the reader approaches the "Interlude" with an open mind on the question of which interpretation of the relation of the individual to the truth is correct, he cannot, I shall argue, leave the "Interlude" similarly open minded. That is not to say that the "Interlude" will attract every reader to the Christian interpretation of existence, but rather that if the reader is not so attracted, then the "Interlude" will serve to actively repel him.

The problem with the "Interlude" is that is assumes what Kierkegaard contends, in the Fragments, he has set out to investigate or to prove. That is, Kierkegaard begins the Fragments with the question of whether it is possible to make an advance upon Socrates by imbuing the moment [Oieblikket] with essential or decisive significance. To put is more plainly: Kierkegaard sets out to determine if there is a way to interpret the relation of the individual to the truth that will make the temporal nature of an individual's existence an essential or decisive aspect of that existence.

The Socratic interpretation of the relation of the individual to the truth reduces the temporal aspect of human existence to something of only accidental significance, and so to preserve substantial significance for the temporal nature of existence, an alternative interpretation of the relation

that were commonly played between the acts of plays. It appears, in fact, that the latter usage was more common, during this period, than the former. There is thus no reason to suppose-as indeed I did when I was first developing the thesis being advanced in this paper-that Kierkegaard's use of "en Symphoni" here is intended to be ironic. I am indebted to Bruce Kirmmse for the above information.

$16_{\text {Ibid., p. } 71 / \text { p. } 67 .}$ 
of the individual to the truth is needed. Klerkegaard thus offers such an alternative to see if it will, in fact, make an advance upon Socrates by preserving the reality of time. We shall see, however, that the thesis of the "Interlude"-i.e., that the actual is no more necessary than the possible, or that nothing comes into existence through necessity-implicitly assumes the reality of time.

The view which Kierkegaard ascribes to Socrates is very pervasive among philosophers. It reaches back through the history of philosophy at least as far as Parmenides. Parmenides contends that either a thing is, and then it

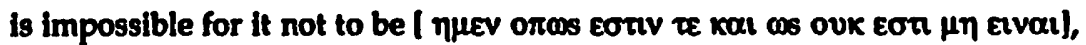
or it is not [n $\delta$ cos oux Eotiv]. ${ }^{17}$ That is, either a thing exists or it does not, but it is impossible, on Parmenides view, to consider that something could exist at one moment that did not exist in the previous moment. Hence, for Parmedides, nothing can be understood to come into existence. What is true, or what is real, on this view, is what is "uncreated and imperishable". ${ }^{18}$ Reality is considered to be timeless and unchanging. Consider the following fragment:

It never was nor will be, since it is now, all together, one, continuous. For what birth will you seek for it? How and whence did it grow? I shall not allow you to say nor to think from not being: for it is not to be said nor thought that it is not; and what need would have driven it Ito bel later rather than earlier, beginning from nothing, to grow? Thus it must either be completely or not at all. Nor will the force of conviction allow anything besides it to come to be ever from not being. Therefore Justice has never loosed her fetters to allow it to come to be or to perish, but holds it fast. And the decision about these things lies in this: it is or it is not...[f]or if it comes into being, it is not: nor is it if it is ever going to be in the future. Thus coming to be is extinguished and perishing is unheard of. ${ }^{19}$

17G. S. Kirk, J. E. Raven, M. Schofield, Presocratic Philosophers (Cambridge: Cambridge University Press, 1983), p. 245.

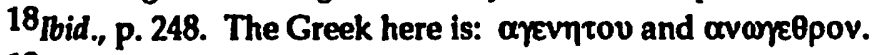

${ }^{19}$ Ibid., pp. 249-50. 
Kierkegaard acknowledges that the contention that something can come into existence is problematic, since it appears to commit one to the view that something comes to exist from nothing, but he attempts to escape this problem with the contention that there is a difference between absolute non-being and the non-being which represents potential being. Kierkegaard contends that

this non-being [Ikke-Veeren] that is abandoned by that which comes into existence must also exist.... But such a being [Vaeren] ${ }^{20}$ that nevertheless is non-being is possibility [Muligheden], and a being that is being is indeed actual being [virkelige Vaeren] or actuality [Virkeligheden] and the change of coming into existence is the transition from possibility to actuality. ${ }^{21}$

Thus Kierkegaard escapes the charge of trying to get something from nothing by contending that possibility is a kind of non-being that, in fact, differs from the non-being which is purely nothing. But Klerkegaard is still not in the position of having made an advance upon Socraties (or upon Parmenides), because it may be argued-as indeed Parmenides would argue-that what comes into existence, in fact, exists already in the form of possibility, and that the change is thus merely in the appearance of the thing and not in its essential being or reality.

The difficultly here hinges upon how one understands the term 'possible'. Aristotle considers that there are at least two senses of the term, and that in one sense it is appropriate to speak of the necessary as being, or as having been, possible-indeed, it would seem self-contradictory to speak of the necessary as being, or as having been, impossible. On this view, one can speak of a particular historical event as having been at one point possible and at the next point having become actual, and yet all the while understanding the event as having been necessary. This is precisely what Kierkegaard wants to avoid, because such talk makes the phenomenon of the coming into existence of a particular event something

20The definite articles in Danish are enclitic. "En" is the common gender definitive article, hence it would appear that Vaeren and Muligheden ought properly to be translated as "the being" and "the possibility" respectively. The definite articles are sometimes used, however, with abstract nouns such as vaeren or doden: 'death'. (N.B. Nouns were capitalized in Danish during Kierkegaard's lifetime. They are no longer capitalized however.)

21 Fragments, pp. 73-74/Samlede Vaerker, Vol. 6, p. 68. 
of merely accidental rather than essential significance. That is, on this view the event may appear to be possible or it may appear to be actual, but the form of its appearance becomes insignificant, for insofar as it is understood to be necessary, then it must be understood to exist even when it appears to be merely possible. It exists in the sense that even when it is in the state of possibility or potentiality, insofar as it is understood as necessary, it negates the possibility of any other event or course of events, a negation which is normally understood to be effected only through the actualization of a particular event.

It is thus a matter of indifference, on this view, whether a particular event appears to be possible, or has already been actualized. But it is precisely this indifference to the change of coming into existence which Kierkegaard desires to overcome.

In his attempt to avoid the possibility of such an indifference, Kierkegaard goes back to examine whether it is proper to consider that possibility can be predicated of the necessary. He argues that the necessary cannot come into existence, or cannot be understood as having been possible, because "Icloming into existence is a change, land] since the necessary is always related to itself and is related to itself in the same way, it cannot be changed at all."22 But if nothing can come into existence through necessity, then everything must come into existence through freedom. Thus Kierkegaard contends that everything which comes into existence-which is to say all historical events-comes into existence through freedom and not through necessity.

On this view, an event would not be said to exist in the form of possibility, rather it would be said that possibility existed. But to say that possibility exists is to say that at that point any number of different events could be actualized. It is in this way that Kierkegaard hopes to make the reader understand the change of coming into existence as one of essential significance and thus persuade the reader that it is not a process to which he should be indifferent.

Although Kierkegaard offers an argument for the views he expresses in the "Interlude", the argument is by no means conclusive. It would appear entirely possible for the Parmenidean to reject the view that the transition from possibility to actuality constitutes a real change. Kierkegaard argues that the necessary cannot come into existence because coming into existence is a change and the necessary cannot change. But if one 
subscribes to the Aristotelian sense of 'possible', then one may argue that coming into existence does not constitute a change in any significant or substantial sense.

Kierkegaard's rejection of Aristotle's view that possibility may be predicated of the necessary seems to stem from the intuition that this is not what we normally mean when we use the term 'possible', but in fact constitutes a perversion of the normal meaning. But even if Kierkegaard's intuition is correct, it may be that our language simple falls to provide us with an adequate description of reality. It may not be legitimate to conclude from the fact that we understand or use the term 'possible' in a particular way, that this tells us something about the true character of existence. It may be that, in fact, nothing is possible in the sense in which we most often use the term.

The effect that what is said in the "Interlude" has upon the Fragments as a whole is clear. The problem of the Fragments, it will be remembered, is the question of whether it is possible for there to be a historical point of departure for an eternal consciousness. The truth is considered eternal; thus it is the nature of the relation of the individual to the truth that becomes the decisive factor in how the question is to be answered.

Insofar as the truth is eternal, consciousness of the truth constitutes, on Kierkegaard's view, "eternal consciousness" [eoig Bevidsthed]. The question is: How does the individual come into possession of the eternal consciousness? On the Socratic view, the individual is seen as essentially in possession of it, but accidentally in a state of forgetfulness. If it seems peculiar to contend that one can be conscious of something one has, in fact, forgotten, it should be remembered, however, that the emphasis here is on 'essentially' and 'accidentally'. The point in time at which the Socratic individual remembers the truth does not represent the point at which he comes into possession of the consciousness of the truth, rather, it marks the point at which he realizes that he has always know the truth. Thus it does not seem possible, on this view, to speak of anything more than an apparent point of departure for the eternal consciousness of the truth, insofar as the individual is understood as actually having been in possession of this consciousness all the time.

As soon as the individual becomes aware that he has always known the truth, he is unable to find the point in time which would normally be understood to have marked his transition from a state of ignorance to a state of knowledge. Thus the point in time at which the individual remembers the truth-and, in fact, the entire changing face of temporal existence-can have nothing more than accidental significance over and against the eternality of the consciousness of which the individual is in possession. 
Climacus contends that he has, at least in principle, no problem with this interpretation of the relation of the individual to the truth, but that he is merely setting out, in the Fragments, to investigate the issue of whether or not there is an alternative interpretation that would preserve essential or decisive significance for the temporal aspect of human existence.

I have already examined the nature of the alternative Climacus offers. He contends that what he is doing in developing such an alternative is merely offering a project for thought. This project, he says "indisputably goes beyond the Socratic, as is apparent at every point. [But] [w]hether it is therefore more true than the Socratic is an altogether different question". ${ }^{23}$ Climacus claims that he has offered, in the Fragments, a disinterested or objective account of what he considers is an exhaustive treatment of the ways in which the individual can be understood to be related to the truth. We can see now, however, that what Kierkegaard offers in the Fragments is by no means as disinterested or objective account as Climachus pretends .

I stated, in section II of this paper, that while Climacus offers the "Interlude" as a piece of light entertainment to distract the reader from consideration of the problem of the Fragments, the question with which the "Interlude" is concerned is by no means unrelated to the problem of the Fragments. If one accepts what is said in the "Interlude" concerning the nature of the transition from possibility to actuality-which is to say, if one rejects the Aristotelian sense in which possibility may be predicated of the necessary then one is committed to the view that the temporal aspect of human existence is of essential or decisive significance. We have seen, however, that the Socratic interpretation of the relation of the individual to the truth deprives temporality of such significance. Thus it would appear that if one accepts what is said in the "Interlude", one is precluded from accepting the Socratic interpretation of existence.

The question is: Why would Kierkegaard deliberately subvert the objectivity of the Fragments in this way? This is not an easy question to answer, but I have worked out a modest theory concerning this apparently perverse action of Kierkegaard's, and I shall offer it to the judgement of the reader in the pages which follow. 


\section{VI}

The disjunction Klerkegaard posits between the Socratic and the Christian interpretations of the relation of the individual to the truth, in fact represents what he would contend is the disjunction between the traditional philosophical understanding of the relation of the individual to the truth-an understanding that, again, goes back as far as Parmenidesand the Christian understanding of that relation.

The traditional philosophical position is that all that is required in order for the individual to come to know the truth is the possession of the faculty of reason or of understanding. As the possession of this faculty is considered, more or less, universal among human beings, this position is not, in any significant respect, distinguished from what Kierkegaard identifies as the "Socratic" position. To possess this faculty is , in essence, to possess the truth. That is, if all that is required in order for an individual to come to understand the truth ts the ability to reason, then insofar as every human being is considered to be capable of such an activity, if a particular individual fails to come to understand the truth, this failure must be viewed as a phenomenon of merely accidental significance; for on this view, the individual must be understood to have been essentially capable of coming to understand the truth, even if he accidentally failed to realize this potential.

Thus what Kierkegaard has done in the Fragments is contrast what he considers is the philosophical interpretation of existence with the Christian interpretation. The irony is that the work purports to be an objective juxtaposition of these two interpretations when, in fact, it is not. The reader may wonder why Kierkegaard would so carefully, and indeed artfully, create in the Fragments the discrepancy identified above between the works appearance-i.e., its pretended objectivity-and its actual bias. It is my view that the answer to this question lies, not surprisingly, in his views concerning indirect communication. Kierkegaard contends that:

the secret of all communication consists precisely in emancipating the recipient, and that for this reason [onel must not communicate himself directly; aye, that it is even irreligious to do so. This last holds true the more subjective is the essence of the matter, and hence applies first and foremost in the religious sphere. 24

${ }^{24}$ Postscript, p. 69/Samlede Vaerker, Vol. 9., p. 64. 
It is my contention, as I stated at the beginning of this essay, that Kierkegaard believes that it is not possible to resolve the debate between the Socratic, or the traditional philosophical interpretation of existence and the Christian interpretation, through a purely objective consideration of the two positions. Indeed, it is my contention that Kierkegaard does not believe that an objective consideration of the issue is even possible.

I believe that Kierkegaard is using the "Interlude" to make an implicit appeal to what he hopes is the individual's subjective experience of freedom. That is, it appears that he is hoping to appeal, through the medium of the "Interlude", to the individual's subjective impression that the choices which punctuate his existence are real and that he thus has a substantive role in the formation of the character of his existence. I believe that Kierkegaard's objective, in making such an appeal, is to reveal indirectly to the reader that the philosophical interpretation of existence fails to preserve any essential or substantive significance for this impression of freedom.

I contended above that if the "Interlude" did not serve to sway the reader in the direction of the Christian interpretation of existence, then it would alienate him even further. The logic behind this contention should now be clear. Insofar as the "Interlude" is understood here to represent Kierkegaard's indirect appeal to the character of the reader's subjective experience, if that experience does not seem to the reader to be one of freedom, but rather of necessity, ${ }^{25}$ then the "Interlude" will simply drive him further away from the Christian interpretation of existence and toward the Socratic/philosophical one. ${ }^{26}$ Kierkegaard's views on the nature of

$25 \mathrm{My}$ temptation is to consider that such a perception of freedom (or of the substantial significance of individual choices) that was described above, is a universal characteristic of human experience. One of my colleagues has informed me, however, that his experience is precisely the opposite. He claims that his impression is that his choices are not really of substantial significance. That is, he claims that his impression is that his cholces are, in fact, determined by the "kind of person" he is.

${ }^{26}$ The reader should resist the temptation to consider that Kierkegaard subscribed to a relativistic position that would consider the Christian interpretation of existence to be true from the individual whose subjective experience had the requisite character, but not true for the individual whose experience was of a different nature. Kierkegaard was no relativist. My suspicion is that he would not have considered the subjective experience of necessity-with the exception of the experience of an apostle, which exception is of no concern to us here-to be authentic, but would have considered it rather to be a symptom of a diseased spirit. The 
communication commit him to the position that to state his belief on this matter in a direct manner would be less effective than presenting it in a manner that appeared antithetical to the content of the belief itself. ${ }^{27}$ It would certainly have been possible for Kierkegaard to have stated the thesis that an objective resolution of the debate between philosophy and Christianity was impossible. Such a presentation would, however, by no means compel the reader to accept the thesis. Thus it would seem that Klerkegaand practically orders his reader to try to resolve this debate in an objective fashion, precisely in order to help the individual to understand that such an objective resolution is impossible.

\section{Conclusion}

If the interpretation of Klerkegaard's Philosophical Fragments and in particular, the interpretation of the significance of the "Interlude" section of the Fragments, provided above is correct, then it is clear that the content of the Fragments, in contrast to its form, is quite consistent with the emphasis that is placed upon subjectivity in the Postscript and that it is thus as valuable a resource for determining the substance of Kierkegaard's thought as this latter work.

Fragments need not, however, be considered to be aimed exclusively at those readers whose spirits were in a sufficient state of health. For, as Kierkegaard points out, it is sometimes necessary to take "measures to disclose the sickness." The Sickness Unto Death, trans. Howard V. Hong and Edna H. Hong [Princeton: Princeton University Press, 1980], p. 23/82. In this instance, the disease of the spirit would be disclosed by the reluctance of the individual to acknowledge the reality of time. For while Kierkegaard would probably find such a position acceptable for a preChristian thinker, it is not a view that he would find acceptable for a nineteenth century Christian-or indeed, a Christian of any century-for it is his view that such a position runs counter to the basic tenets of Christianity. Hence part of the objective of the Fragments is probably to expose the disease, or hypocrisy, of giving lip-service to the freedom of the human will, while simultaneously subscribing to a more fundamental metaphysical position which would preclude the existence of such freedom.

27 See note 5 above. Much of Kierkegaard's position concerning the nature of communication is also contained, however, in the discussions concerning the relation between the teacher and the learner, which occur in the Fragments and Johannes Climacus. 
It is, however, always open to the reader to consider that Kierkegaard is unaware of the precise theoretical significance of the "Interlude" and in particular of the consequences which the adoption of the position contained therein has in relation to the question with which the Fragments is primarily concerned-i.e., the question of the nature of the relation of the Individual to the truth. But if this is the position one desires to maintain, then one is left with the burden of establishing alternative motivation for Kierkegaard's insertion of the "Interlude" in the Fragments. The substance of the "Interlude" clearly precludes the responsible reader from an uncritical acceptance of Climacus' contention that it is not his belief that the "matter" with which the "Interlude" is concerned "definitely require" $[s]^{\prime 28}$ the consideration of the reader. It is quite clear that, despite Climacus' protests to the contrary, Kierkegaard is accusing the reader of "not fully understanding (him]self in this regard."29 But if the Fragments is intended by Kierkegaard to be an objective examination of the relation of the individual to the truth, why is the failure of the reader to understand himself, in any respect, important?

I believe that the interpretation of the Fragments presented in this essay provides the least contrived, or most coherent, account of the significance of the "Interlude" and hence of the Fragments more generally, as it is perhaps possible to offer. If this seems a contentious claim (and it very likely is), it should be taken by the reader as a challenge to provide a yet more coherent or persuasive interpretation of this work of Kierkegaard's that is, I believe, one of the richest of resources for determining the substance of his thought.

28 Fragments, p. 73/Samlede Vaerker, Vol. 6, p. 67.

$29_{\text {Ibid., p. 73/p. } 67 .}$ 